\title{
School Administrators Skills in Organizing the Parent Participation Studies
}

\author{
Canan Albez ${ }^{1}$, Şükrü Ada ${ }^{2}$ \\ ${ }^{1}$ Pre-school Teacher, Alparslan Primary School, Erzurum, Turkey \\ ${ }^{2}$ Assoc. Prof. Dr., Uludağ University-Faculty of Education-Faculty Staff at Department of Educational Sciences, Bursa, \\ Turkey
}

Correspondence: Canan Albez, Palandöken Alparslan Primary School, Erzurum, Turkey.

Received: February 3, 2017 Accepted: March 5, $2017 \quad$ Online Published: March 20, 2017

doi:10.11114/jets.v5i4.2184 URL: https://doi.org/10.11114/jets.v5i4.2184

\begin{abstract}
The objective of this study is to ascertain administrator, teacher and parent opinions on the level of school administrators' skills of organising parent participation efforts. The study group of the study conducted according to the descriptive survey model using the quantitative method consists of 273 school administrators, 916 teachers and 395 parents from primary schools, secondary schools and high schools, determined according to the stratified sampling method. The quantitative data of the research were obtained through the 'scale for school administrators' skills of organising parent participation efforts' applied to school administrators, teachers and parents after the validity reliability studies were conducted. The study reached the conclusion that school administrators' skills in organising parent participation efforts and the parent participation efforts conducted were inadequate.
\end{abstract}

Keywords: school administrator, parent participation

\section{Introduction}

There exists a communion between school administrators, teachers, parents and students, who are members of the school community, arising from multi-faceted relations. What is essential to this communion is to capture harmony between the family environment, where individuals experience their first learning processes, and classroom and school practices, which will complement this learning and bring depth into the child's life; to ensure a harmonious and coherent collaboration between all parties responsible for the child's development, training and education, and to carry out the purposes of schooling.

Studies conducted indicate that school - family collaboration has a positive effect on success at school (Epstein, 1995; Parker, Boak, Griffin, Ripple and Peay, 1999; Şişman, 2002; Fantuzzo, McWayne, Perry and Childs, 2004; Gestwicki, 2004; Lindberg, 2014). Parents' participation in classroom and school practices increases students' attendance at school. Also, individuals who are supported by their parents at home as well as at school have more developed self-management and self-control skills, and, being positively motivated to learn, they are more willing to study (Danielson, 2002; Rosenblatt and Peled, 2002, Dempsey and Battiato, 2001; Eccles and Harold, 1993).

The school's targets must cover including parents in the efforts made by the school in connection with children's education and together developing a 'partnership programme approach', thus reaching out to a larger number of families and ensuring that the student adopts greater objectives for the future. Viewed from this angle, educationalists, families and the community must work together in order to assist the students in their success and to create an accepted school environment (Epstein and Jansorn, 2004a, Riley, 1994). School administrators have an important role in ensuring this partnership.

In Turkey, various implementations of family and environment participation programmes in education are observed. Some of these are: parents sharing their professional fields and areas of interest with students within the framework of curricula; implementation, by the family, of home programmes prepared in accordance with curricula; creating

\footnotetext{
*This study is based on the $\mathrm{PhD}$ dissertation of the same title, accepted by the Atatürk University Institute of Educational Sciences in December 2016.
} 
resources for the school's needs; opening, and encouraging the opening of, school areas for use by the community; ensuring participation by the community to, and increasing families' cultural levels by, activities such as environmental health, hygiene, family planning, literacy, computer courses and educational conferences (MEB, 1997, 7-8).

The Ministry of National Education, Social Activities Regulations for Primary and Secondary Schools provides for the participation of parents. The Social Activities Board consists of an advisor teacher chosen from among advisor teachers, three students chosen by club representatives from among their numbers, and two parents representing the parent teacher association, and is chaired by a deputy principal to be charged by the principal (Article 8). The volunteer parents to assist students in their social activity works are elected at the parent - teacher association meeting at the beginning of the academic year, after the introduction of the duties and responsibilities of the volunteer parents (Article 9). Along with the other members, the Social Activities Board includes two parents representing the parent - teacher association and three students chosen by club representatives from among their numbers. It is also underlined that volunteer parents may be elected to assist teachers in developing and implementing projects related to social activities.

The parent participation works carried out at schools to this end are conducted as five processes, namely 'familiarisation, participation to management, participation in classroom applications, conducting social activities and student personality services, resolution of discipline issues' (Özbaş and Badavan 2009; Yiğit and Bayrakdar, 2006; Türkmen, 2005).

While regulating parent - school relations under these processes, the school administration takes the 'Parent - Teacher Association Regulations' as basis. Accordingly, parent - teacher associations are established in order to 'ensure integration between the school and the family, ensure communication and collaboration between parents and the school, provide the necessities of students without means, and make pecuniary contributions to the school' (MEB, 2005). However, the financial functions of parent - teacher associations in meeting the school's needs have risen above their priority functions (Nural, Kaya and Kaya, 2013; Bayrakçı and Dizbay, 2013). Acording to Yılmaz (1994), the 'Parent Teacher Association', which was originally established in order to regulate the relations between the school and the family, which are very important in preparing students for life, has become a nominal institution, far from carrying out its duties set forth in the regulations in question. Parent - Teacher Associations make no contribution to developing students' sense of responsibility, although this is listed in the Parent - Teacher Association Regulations as being among the objectives of the association. Ensuring parents' use of the buildings and facilities of schools was not successful. Teachers are not encouraged to conduct family visits, while parents are not illuminated on the purposes of the school, the principles of education, and the activities conducted at school. Also, it is not possible to speak about regular and effective communication between the school administration and the parent - teacher association, which was formed in order to develop collaboration between the school and the families (Akbaşlı and Kavak, 2008; Aydoğan, 2006; Şişman and Turan, 2002; Aytaç, 2000).

This research was conducted for the purpose of examining school administrators' skill in organising parent participation efforts based on the duties assigned to the school administration in planning and conducting the efforts aimed at developing collaboration between the school and parents, and the answers to the following questions were sought:

1) With regard to the level of school administrators' skills in organising parent participation efforts;

a) What are the administrators', teachers' and parents' opinions?

b) Do administrators', teachers' and parents' opinions vary in terms of steps of organisation?

2) Does the level of school administrators' skills in organising parent participation efforts vary according to the school type variable?

\section{Method}

\subsection{Research Model}

The research examining school administrators' skill in organising parent participation efforts is a descriptive study conducted in the relational survey model from among the administrator, teacher and parent perception quantitative research patterns.

\subsection{Population and Sample}

In the study's quantitative section, the population consisting of school administrators comprises a total of 351 school administrators consisting of school principals and deputy principals working at 30 high schools, 40 secondary schools and 45 primary schools at the Erzurum central district during the 2013 - 2014 academic year. The population of the study consisting of teachers comprises 3831 teachers from primary schools, secondary schools and high schools. Due to the fact that parent - teacher association executive board members participate directly in parent - teacher participation efforts, in the study the population consisting of parents comprises 575 parents, 30 of which are members of executive 
boards of parent - teacher associations in high schools, 40 in secondary schools and 45 in primary schools. The sample size of the study consists of 273 school administrators, 916 teachers and 395 parents from primary schools, secondary schools and high schools, determined according to the stratified sampling method.

\subsection{Data Collection Tools}

The quantitative data of the research were obtained through the 'scale for school administrators' skills of organising parent participation efforts', developed by the researcher by obtaining expert opinion and applied to school administrators, teachers and parents after the validity - reliability studies were conducted. The scale was prepared taking four dimensions of the organisation process, namely 'construction, works required, staffing and equipping, organisational climate' into consideration, and each dimension was assessed as a sub-scale.

The construct validity of the scale was examined through a factor analysis. To this end, the preliminary application of the scale was carried out during second semester of the 2013 - 2014 academic year. 142 teachers, 35 school administrators and 30 parents commissioned at primary schools, secondary schools and high schools at the Erzurum central district participated in the preliminary application. The Kaiser - Meyer - Olkin (KMO) test was applied in order to determine whether a factor analysis would be applied to the data obtained as a result of the preliminary application. It is recommended that the smallest KMO value should be over 0.60 in order that a factor analysis may be conducted on the data (Tavşancıl, 2005, 50). The KMO value for 40 items related to the scale was found to be .945 . As the value obtained was greater than 0.60 , it was understood that a factor analysis could be applied to the data. A Barlett's test was conducted to examine the normality distribution of the data. This analysis found that the data were significant at the level of 0.000 . Table 1 presents the KMO and Barlett's test results for the scale.

Table 1. KMO and Barlett's Test Results

\begin{tabular}{lll}
\hline Kaiser-Meyer-Olkin Measurement for the Adequacy of the Sample & .945 \\
Barlett's Test & Chi-Square Estimation & 6071.170 \\
& Sd & 780 \\
& Significance Level & .000
\end{tabular}

A factor analysis was conducted to determine whether the scale was a single- or multiple-factor scale. To this end, the principal components analysis, which is a factor analysis technique was conducted over the data, while the Varimax Vertical Rotation Method was employed to determine the scale's independent sub-factors. These two analyses revealed that the scale was a multi-factor scale. Especially when the "Total Variance Explained" table was examined, 6 factors with an eigenvalue over 1 were found. The total contribution of these 6 factors to the variance was $62.455 \%$. Examining the contributions each of the factors made to the variance as indicate in the "\% of variance" column of the "Initial Eigenvalues" section, it was seen that the contribution decreased after the third factor, and the difference between these was very close. This indicates that there may exist four factors. Within this context, the "Scree plot" graph was examined, and it was considered that the questionnaire items should be gathered under the 4 factors taken as basis in preparing the scale. As seen in Table 2, the variance ratios indicated by the factors were $5.61 \%$ for the first factor, $4.89 \%$ for the second, $3.34 \%$ for the third, and $42.73 \%$ for the fourth factor. The reliability coefficient calculated for the first factor of the scale was .91 , while this coefficient was .89 for the second, .88 for the third and .92 for the fourth.

Table 2. Sub-Factors and Variance Ratios of the Process of Organising Parent Involvement Efforts

\begin{tabular}{lll}
\hline Factor & Variance Indicated & \% Alpha \\
\hline Construction Formation & 5.61 & .91 \\
Works Required & 4.89 & .89 \\
Staffing and Equipping & 3.34 & .88 \\
Organisational Climate & 42.73 & .92
\end{tabular}

\subsection{Analysis of the Data}

In the scale prepared using the Likert-type five point grading approach, the "never" option was given 1 point, "rarely" 2 points, "sometimes" 3 points, "mostly" 4 points, and "always" 5 points. By dividing the number of intervals in the grading scale by the number of options $(4 / 5=0.80)$, the points to be used in assessing the items were found. Accordingly, the point interval of "none" was 1.00 - 1.79, "little" was 1.80 - 2.59, "medium" was 2.60 - 3.39, "many" was $3.40-4.19$, and the point interval of "full" was found to have a value of $4.20-5.00$. The arithmetic mean and standard deviation values were used in interpreting the data obtained in the quantitative part of the study. As it was seen that the research scale corresponded to the parametric test assumptions, the t-test was used in binary comparisons, while 
a one-way analysis of variance was used in the comparison of more than two variants. A significance level of .05 was taken into consideration in interpreting the trials and findings.

\section{Findings}

\subsection{Construction Skills of Administrators in Organising Parent Involvement Efforts}

Table 3 presents the arithmetic mean and standard deviation values of the opinions of administrators, teachers and parents regarding school administrators' skills in construction in the process of organising parent participation efforts. Table 3. Administrator, Teacher and Parent Opinions on the Construction Dimension in the Organisation of Parent Involvement Efforts

\begin{tabular}{|c|c|c|c|c|c|}
\hline Scale Items & Group & $\mathrm{N}$ & $\bar{X}$ & SS & $\mathrm{V}$ \\
\hline \multirow[t]{3}{*}{ Conducts research on school - parent collaboration. } & Administrator & 273 & 3,76 & ,906 & 24,09 \\
\hline & Teacher & 916 & 3,25 & ,989 & 30,43 \\
\hline & Parent & 395 & 3,03 & 1,12 & 36,96 \\
\hline \multirow{3}{*}{$\begin{array}{l}\text { It determines the objectives of parent participation efforts in accordance with } \\
\text { the needs and expectation of teachers, parents and students. }\end{array}$} & Administrator & 273 & 3,97 & ,863 & 21,73 \\
\hline & Teacher & 916 & 3,42 & ,953 & 27,86 \\
\hline & Parent & 395 & 3,10 & 1,04 & 33,54 \\
\hline \multirow{3}{*}{$\begin{array}{l}\text { Expresses the objectives of parent participation efforts in an open and clear } \\
\text { manner. }\end{array}$} & Administrator & 273 & 3,96 & ,975 & 24,62 \\
\hline & Teacher & 916 & 3,53 & 968 - r r & 27,42 \\
\hline & Parent & 395 & 3,36 & 1,05 & 31,25 \\
\hline \multirow{3}{*}{$\begin{array}{l}\text { Prepares the most suitable environment to ensure school-parent } \\
\text { collaboration. }\end{array}$} & Administrator & 273 & 4,23 & ,849 & 20,07 \\
\hline & Teacher & 916 & 3,59 & ,995 & 27,71 \\
\hline & Parent & 395 & 3,26 & 1,06 & 32,51 \\
\hline \multirow[t]{3}{*}{ Ensures the parents' and the environment's trust and support to the school. } & Administrator & 273 & 4,26 & ,842 & 19,76 \\
\hline & Teacher & 916 & 3,64 & ,988 & 27,14 \\
\hline & Parent & 395 & 3,48 & 1,06 & 30,45 \\
\hline \multirow{3}{*}{ Utilises the resources of the school and environment in an effective manner. } & Administrator & 273 & 3,93 & ,943 & 23,99 \\
\hline & Teacher & 916 & 3,51 & 992 & 28,26 \\
\hline & Parent & 395 & 3,18 & ,998 & 31,38 \\
\hline \multirow{3}{*}{ Considers criticism against the school and takes the necessary steps. } & Administrator & 273 & 4,25 & ,822 & 19,34 \\
\hline & Teacher & 916 & 3,54 & 1,01 & 28,53 \\
\hline & Parent & 395 & 3,27 & 1,08 & 33,02 \\
\hline \multirow[t]{3}{*}{ Collaborates with corporations and institutions related to education } & Administrator & 273 & 4,01 & ,925 & 23,06 \\
\hline & Teacher & 916 & 3,52 & 1,01 & 28,69 \\
\hline & Parent & 395 & 3,25 & 1,13 & 34,76 \\
\hline \multirow{3}{*}{$\begin{array}{l}\text { Creates a democratic communication environment for parents, based on } \\
\text { respect and trust. }\end{array}$} & Administrator & 273 & 4,31 & ,784 & 18,19 \\
\hline & Teacher & 916 & 3,76 & 987 - - & 26,25 \\
\hline & Parent & 395 & 3,58 & ,981 & 27,40 \\
\hline \multirow[t]{3}{*}{ Encourages teachers and parents in developing parent participation efforts. } & Administrator & 273 & 4,04 & ,912 & 22,57 \\
\hline & Teacher & 916 & 3,47 & 1,05 & 30,25 \\
\hline & Parent & 395 & 3,23 & 1,04 & 32,19 \\
\hline \multirow[t]{3}{*}{ Classifies school - parent collaboration efforts according to type. } & Administrator & 273 & 3,66 & ,917 & 25,05 \\
\hline & Teacher & 916 & 3,12 & 1,04 & 33,33 \\
\hline & Parent & 395 & 2,78 & 1,13 & 40,64 \\
\hline \multirow{3}{*}{$\begin{array}{l}\text { The parent - teacher association ensures the effective participation of the } \\
\text { school development and administration team in the school's administration. }\end{array}$} & Administrator & 273 & 3,93 & 910 & 23,15 \\
\hline & Teacher & 916 & 3,34 & 1,02 & 30,53 \\
\hline & Parent & 395 & 3,24 & 1,10 & 33,95 \\
\hline \multirow[t]{3}{*}{ Average } & Administrator & 273 & 4,03 & ,670 & 16,62 \\
\hline & Teacher & 916 & 3,47 & ,802 & 23,11 \\
\hline & Parent & 395 & 3,23 & 1,06 & 32,81 \\
\hline
\end{tabular}

According to Table 3, the arithmetic average of the answers provided by administrators, teachers and parents to the scale items for determining the participation levels of school administrators to skills in construction in the process of organising parent participation efforts is $\bar{X}_{\mathrm{A}}=4,03, \bar{X}_{\mathrm{T}}=3,47, \bar{X}_{\mathrm{P}}=3,23$. According to these results, it is seen that the skills required by the construction phase in the process of organising parent participation efforts is adopted frequently by school administrators and teachers, and sometimes by parents. While school administrators' skills in construction in the process of organising parent participation efforts are considered inadequate by parents and teachers, this is considered adequate by school administrators.

Table 4 provides a comparison between administrator, teacher and parent opinions on the construction process in organising parent participation efforts. 
Table 4. Differences between the Opinions of Administrators, Teachers and Parents on the Level of Administrators' Construction Skills in Organising Parent Involvement Efforts

\begin{tabular}{lllllll}
\hline Groups & $\mathrm{N}$ & $\bar{X}$ & $\mathrm{SS}$ & $\mathrm{Sd}$ & $\mathrm{t}$ & $\mathrm{p}$ \\
\hline Administrator & 273 & 4,03 &, 670 & 1187 & 10,333 &, $000^{*}$ \\
Teacher & 916 & 3,47 &, 802 & & & \\
Administrator & 273 & 4,03 &, 670 & 666 & 14,187 &, $000^{*}$ \\
Parent & 401 & 3,23 &, 738 & & & \\
Teacher & 916 & 3,47 &, 802 & 1309 & 5,152 &, $000^{*}$ \\
Parent & 401 & 3,23 &, 738 & & & \\
$\mathrm{p}<.001$ & & & & & &
\end{tabular}

According to Table 4, when school administrators' skill in construction in the process of organising parent participation efforts is assessed in terms of the duty type variable, there appears a statistically significant difference $\left[t_{(1-1188)}=10,333\right.$, $\mathrm{p}<.001]$ in favour of the administrator in the administrator - teacher group, $\left[\mathrm{t}_{(1-673)}=14,187, \mathrm{p}<.001\right]$ in favour of the administrator in the administrator - parent group, and $\left[\mathrm{t}_{(1-1316)}=5,152, \mathrm{p}<.001\right]$ in favour of the teacher in the teacher-parent group.

\subsection{Administrators' Skills of Determining the Required Efforts in Organising Parent Involvement Efforts}

Table 5 presents the arithmetic mean and standard deviation values of the opinions of administrators, teachers and parents regarding school administrators' skills in determining the required efforts in the process of organising parent participation efforts.

Table 5. Administrator, Teacher and Parent Opinions on the Required Efforts Dimension in the Organisation of Parent Involvement Efforts

\begin{tabular}{|c|c|c|c|c|c|}
\hline Scale Items & Group & $\mathrm{N}$ & $\bar{X}$ & SS & $\mathrm{V}$ \\
\hline \multirow{3}{*}{$\begin{array}{l}\text { Regulates the parent education programmes in accordance with the } \\
\text { set objectives. }\end{array}$} & Administrator & 273 & 3,11 & ,928 & 29,83 \\
\hline & Teacher & 916 & 2,88 & 1,22 & 42,36 \\
\hline & Parent & 395 & 2,78 & 1,56 & 56,11 \\
\hline \multirow{3}{*}{$\begin{array}{l}\text { Harmonises parent education programmes with the school's } \\
\text { training - education programmes. }\end{array}$} & Administrator & 273 & 3,38 & ,993 & 29,37 \\
\hline & Teacher & 916 & 3,09 & 1,76 & 56,95 \\
\hline & Parent & 395 & 2,86 & 1,22 & 42,65 \\
\hline \multirow[t]{3}{*}{ Ensures that parents make class visits. } & Administrator & 273 & 3,43 & 1,12 & 32,65 \\
\hline & Teacher & 916 & 2,91 & 1,76 & 60,48 \\
\hline & Parent & 395 & 3,03 & 2,41 & 79,53 \\
\hline \multirow{3}{*}{$\begin{array}{l}\text { Arranges art, culture and sports activities to increase parents' } \\
\text { participation in the school. }\end{array}$} & Administrator & 273 & 3,45 & 2,65 & 76,81 \\
\hline & Teacher & 916 & 2,77 & 2,00 & 72,20 \\
\hline & Parent & 395 & 2,51 & 1,33 & 52,98 \\
\hline \multirow{6}{*}{$\begin{array}{l}\text { Provides supporting learning opportunities through parent } \\
\text { participation efforts for students whose learning needs are not } \\
\text { adequately met. } \\
\text { Produces new projects addressing school - parent collaboration. }\end{array}$} & Administrator & 273 & 3,45 &, 942 & 27,30 \\
\hline & Teacher & 916 & 2,98 & 1,02 & 34,22 \\
\hline & Parent & 395 & 2,76 & 1,16 & 42,02 \\
\hline & Administrator & 273 & 3,37 & 1,03 & 30,56 \\
\hline & Teacher & 916 & 2,85 & 1,38 & 48,42 \\
\hline & Parent & 395 & 2,68 & 2,25 & 83,95 \\
\hline \multirow{6}{*}{$\begin{array}{l}\text { Allows the school's facilities such as sports hall, library, } \\
\text { laboratory, classroom etc. to be used by parents in the interest of } \\
\text { the public. } \\
\text { Determines the duty areas and responsibilities related to parent } \\
\text { participation efforts. }\end{array}$} & Administrator & 273 & 3,19 & 1,08 & 33,85 \\
\hline & Teacher & 916 & 2,71 & 1,69 & 62,36 \\
\hline & Parent & 395 & 2,38 & 1,31 & 55,04 \\
\hline & Administrator & 273 & 3,62 & 1,99 & 54,97 \\
\hline & Teacher & 916 & 3,01 & 1,06 & 35,21 \\
\hline & Parent & 395 & 2,84 & 1,11 & 39,08 \\
\hline \multirow[t]{3}{*}{ Average } & Administrator & 273 & $\mathbf{3 , 3 8}$ & ,856 & 25,32 \\
\hline & Teacher & 916 & 2,90 & ,925 & 31,89 \\
\hline & Parent & 395 & 2,73 & ,924 & 33,84 \\
\hline
\end{tabular}

According to Table 5, the arithmetic average of the opinions of administrators, teachers and parents on the level of the school administrators' skills in organising parent participation efforts is $\bar{X}_{\mathrm{A}}=4,03, \bar{X}_{\mathrm{T}}=3,47, \bar{X}_{\mathrm{P}}=3,23$. Accordingly, it is seen that the skills required by the stage of determining the efforts to be made during the organisation process for parent participation efforts is adopted at the level of sometimes by school administrators, teachers and parents. Table 6 provides a comparison between administrator, teacher and parent opinions on determining the efforts to be made in organising parent participation efforts. 
Table 6. Differences between Administrator, Teacher and Parent Opinions on the Required Efforts Dimension in the Organisation of Parent Involvement Efforts

\begin{tabular}{lllllll}
\hline Groups & $\mathrm{N}$ & \multicolumn{1}{l}{} & $\mathrm{SS}$ & $\mathrm{Sd}$ & $\mathrm{t}$ & $\mathrm{p}$ \\
\hline Administrator & 273 & 3,38 &, 856 & 1187 & 7,583 &, $000^{*}$ \\
Teacher & 916 & 2,90 &, 925 & & & \\
Administrator & 273 & 3,38 &, 856 & 666 & 9,117 &, $000^{*}$ \\
Parent & 395 & 2,73 &, 924 & & & \multirow{2}{*}{$003^{* *}$} \\
Teacher & 916 & 2,90 &, 925 & 1309 & 3,013 & \\
Parent & 395 & 2,73 &, 924 & & & \\
\hline
\end{tabular}

$$
\text { * } \mathrm{p}<.001{ }^{* * *} \mathrm{p}<.01
$$

According to Table 6, when the level of school administrators' skill in determining the efforts to be made in the process of organising parent participation efforts is assessed in terms of the duty type variable, there appears a statistically significant difference $\left[\mathrm{t}_{(1-1188)}=7,583, \mathrm{p}<.001\right]$ in favour of the administrator in the administrator - teacher group, $\left[\mathrm{t}_{(1-673)}=9,117, \mathrm{p}<.001\right]$ in favour of the administrator in the administrator - parent group, and $\left[\mathrm{t}_{(1-1316)}=3,013, \mathrm{p}<.01\right]$ in favour of the teacher in the teacher-parent group. Taking the averages into consideration, school administrators' skills in determining the efforts to be made in the process of organising the parent participation efforts are considered inadequate by teachers and parents.

\subsection{Administrators' Staffing and Equipping Skills in Organising Parent Involvement Efforts}

Table 7 presents the arithmetic mean and standard deviation values of the opinions of administrators, teachers and parents regarding school administrators' skills in staffing and equipping in the process of organising parent participation efforts.

Table 7. Administrator, Teacher and Parent Opinions on Staffing and Equipping in the Organisation of Parent Involvement Efforts

\begin{tabular}{|c|c|c|c|c|c|}
\hline Scale Items & Group & $\mathrm{N}$ & $\bar{X}$ & SS & $\mathrm{V}$ \\
\hline \multirow{3}{*}{$\begin{array}{l}\text { Identifies teachers and parents to take on tasks in parent participation } \\
\text { efforts. }\end{array}$} & Administrator & 273 & 3,69 & ,962 - & 26,07 \\
\hline & Teacher & 916 & 3,40 & 2,17 & 63,82 \\
\hline & Parent & 395 & 3,05 & 1,16 & 38,03 \\
\hline \multirow{3}{*}{$\begin{array}{l}\text { Explains parents and school personnel charged with parent } \\
\text { participation tasks their duties in their outlines. }\end{array}$} & Administrator & 273 & 3,95 & 3,22 & 81,51 \\
\hline & Teacher & 916 & 3,29 & 1,24 & 37,68 \\
\hline & Parent & 395 & 3,10 & 1,27 & 40,96 \\
\hline \multirow{3}{*}{$\begin{array}{l}\text { The parent - school association grants powers equivalent to the } \\
\text { responsibilities of those working in the school development and } \\
\text { administration team. }\end{array}$} & Administrator & 273 & 3,68 & ,904 & 24,56 \\
\hline & Teacher & 916 & 3,28 & 1,42 & 43,29 \\
\hline & Parent & 395 & 3,06 & 1,92 & 62,74 \\
\hline \multirow{3}{*}{$\begin{array}{l}\text { Openly and clearly defines the duty collaboration between the } \\
\text { administration, the teacher and the parent in parent participation } \\
\text { efforts. }\end{array}$} & Administrator & 273 & 3,85 &, 883 & 22,93 \\
\hline & Teacher & 916 & 3,29 & 1,04 & 31,61 \\
\hline & Parent & 395 & 3,14 & 1,14 & 36,30 \\
\hline \multirow{3}{*}{$\begin{array}{l}\text { Defines the roles and statuses of parents and teachers in parent } \\
\text { participation efforts. }\end{array}$} & Administrator & 273 & 3,76 & ,924 & 24,57 \\
\hline & Teacher & 916 & 3,27 & 1,05 & 32,11 \\
\hline & Parent & 395 & 2,92 & 1,16 & 39,72 \\
\hline \multirow{3}{*}{$\begin{array}{l}\text { Ensures parents' participation in decision-making processes at the } \\
\text { school. }\end{array}$} & Administrator & 273 & 3,60 & ,961 & 26,69 \\
\hline & Teacher & 916 & 3,09 & 1,04 & 33,65 \\
\hline & Parent & 395 & 2,95 & 1,07 & 36,27 \\
\hline \multirow{3}{*}{$\begin{array}{l}\text { Ensures that those charged with duties in parent participation efforts } \\
\text { are responsible only towards the administrator. }\end{array}$} & Administrator & 273 & 3,43 & 1,05 & 30,61 \\
\hline & Teacher & 916 & 3,21 & 1,04 & 32,39 \\
\hline & Parent & 395 & 3,06 & 1,19 & 38,88 \\
\hline \multirow[t]{3}{*}{ Average } & Administrator & 273 & 3,71 &, 874 & 23,55 \\
\hline & Teacher & 916 & 3,26 & ,939 & 28,80 \\
\hline & Parent & 395 & 3,04 & ,930 & 30,59 \\
\hline
\end{tabular}

According to Table 7, the arithmetic average of the opinions of administrators, teachers and parents on the level of the school administrators' skills in staffing and equipping in organising parent participation efforts is, $\bar{X}_{\mathrm{A}}=3,71, \bar{X}_{\mathrm{T}}=3,26$, $\bar{X}_{\mathrm{P}}=3,04$. According to these results, it is seen that the skills required by the staffing and equipping phase in the process of organising parent participation efforts is adopted at the level of frequently by school administrators, and at the level of sometimes by parents and teachers.

According to Table 8, when the level of school administrators' skill in staffing and equipping in the process of organising parent participation efforts is assessed in terms of the duty type variable, there appears a statistically significant difference $\left[\mathrm{t}_{(1-1188)}=7.018, \mathrm{p}<.001\right]$ in favour of the administrator in the administrator-teacher group, [t $\mathrm{t}_{(1-673)=}$ $9.389, \mathrm{p}<.001]$ in favour of the administrator in the administrator-parent group, and $[\mathrm{t}(1-1316)=3.960, \mathrm{p}<.001]$ in favour of the teacher in the teacher-parent group. Taking the averages into consideration, school administrators' staffing and 
equipping skills in the process of organising the parent participation efforts are considered adequate by administrators, while being considered inadequate by teachers and parents.

Table 8. Differences between Administrator, Teacher and Parent Opinions on Staffing and Equipping in the Organisation of Parent Involvement Efforts

\begin{tabular}{|c|c|c|c|c|c|c|}
\hline Groups & $\mathrm{N}$ & $\bar{X}$ & SS & $\mathrm{Sd}$ & $\mathrm{t}$ & $\mathrm{p}$ \\
\hline Administrator & 273 & 3,71 & ,874 & 1187 & 7,018 &, $000^{*}$ \\
\hline Teacher & 916 & 3,26 & ,939 & & & \\
\hline Administrator & 273 & 3,71 & 874 & 666 & 9,389 &, $000^{*}$ \\
\hline Parent & 395 & 3,04 & ,930 & & & \\
\hline Teacher & 916 & 3,26 & ,939 & 1309 & 3,960 &, $000^{*}$ \\
\hline Parent & 395 & 3,04 & ,930 & & & \\
\hline
\end{tabular}

$* \mathrm{p}<.001$

\subsection{Administrators' Skills Ensuring Organisational Climate in Organising Parent Involvement Efforts}

Table 9 presents the arithmetic mean and standard deviation values of the opinions of administrators, teachers and parents regarding school administrators' skills in ensuring the organisational climate in the process of organising parent participation efforts.

Table 9. Administrator, Teacher and Parent Opinions on the Organisational Climate Dimension in the Organisation of Parent Involvement Efforts

\begin{tabular}{|c|c|c|c|c|c|}
\hline Scale Items & Group & $\mathrm{N}$ & $\bar{X}$ & SS & $\mathrm{V}$ \\
\hline \multirow{3}{*}{$\begin{array}{l}\text { Makes use of school - parent collaboration for the success of the education } \\
\text { carried out at school. }\end{array}$} & Administrator & 273 & 3,91 & ,861 & 22,02 \\
\hline & Teacher & 916 & 3,43 & 1,03 & 30,02 \\
\hline & Parent & 395 & 3,19 & 1,04 & 32,60 \\
\hline \multirow[t]{3}{*}{ Makes use of school - parent collaboration in solving discipline issues. } & Administrator & 273 & 3,97 & ,969 & 24,40 \\
\hline & Teacher & 916 & 3,55 & 1,01 & 28,45 \\
\hline & Parent & 395 & 3,36 & 1,03 & 30,65 \\
\hline \multirow{3}{*}{$\begin{array}{l}\text { Makes use of school - parent collaboration in developing social activities and } \\
\text { student personality services. }\end{array}$} & Administrator & 273 & 3,83 & ,999 & 26,08 \\
\hline & Teacher & 916 & 3,35 & ,975 & 29,10 \\
\hline & Parent & 395 & 3,10 & 1,11 & 35,80 \\
\hline \multirow[t]{3}{*}{ Makes arrangements to increase the efficiency of parent-teacher meetings. } & Administrator & 273 & 3,91 & ,943 & 24,11 \\
\hline & Teacher & 916 & 3,40 & 1,70 & 50 \\
\hline & Parent & 395 & 3,50 & 3,49 & 99,71 \\
\hline \multirow[t]{3}{*}{ Regularly organises teacher - parent meetings. } & Administrator & 273 & 3,92 & ,930 & 23,72 \\
\hline & Teacher & 916 & 3,50 & 1,71 & 48,85 \\
\hline & Parent & 395 & 3,18 & 1,13 & 35,53 \\
\hline \multirow[t]{3}{*}{ Collaborates with parents in supporting students requiring special education. } & Administrator & 273 & 3,82 & 1,06 & 27,74 \\
\hline & Teacher & 916 & 3,25 & 1,05 & 32,30 \\
\hline & Parent & 395 & 3,14 & 3,14 & 1.00 \\
\hline \multirow{3}{*}{$\begin{array}{l}\text { Shares the success of the school and its contributions to the environment with } \\
\text { the parents. }\end{array}$} & Administrator & 273 & 3,95 & ,963 & 24,37 \\
\hline & Teacher & 916 & 3,45 & 1,06 & 30,72 \\
\hline & Parent & 395 & 3,30 & 1,10 & 33,33 \\
\hline \multirow{3}{*}{$\begin{array}{l}\text { Informs parents on efforts directly addressing students, such as guidance and } \\
\text { student personality services at school. }\end{array}$} & Administrator & 273 & 3,95 & ,938 & 23,74 \\
\hline & Teacher & 916 & 3,42 & 1,04 & 30,40 \\
\hline & Parent & 395 & 3,30 & 1,85 & 56,06 \\
\hline \multirow{3}{*}{$\begin{array}{l}\text { Ensures the two way flow of all information, emotions and news during the } \\
\text { progress of the parent participation efforts. }\end{array}$} & Administrator & 273 & 3,90 & ,862 & 22,10 \\
\hline & Teacher & 916 & 3,30 & 1,02 & 30,90 \\
\hline & Parent & 395 & 3,12 & 1,08 & 34,61 \\
\hline \multirow{3}{*}{$\begin{array}{l}\text { Solves conflicts between the school and parents in a manner that increases the } \\
\text { school's efficiency. }\end{array}$} & Administrator & 273 & 3,98 & ,909 & 22,83 \\
\hline & Teacher & 916 & 3,47 & 1,10 & 31,70 \\
\hline & Parent & 395 & 3,27 & 1,11 & 33,94 \\
\hline \multirow{3}{*}{$\begin{array}{l}\text { Creates opportunities to develop school - parent collaboration in carrying out } \\
\text { solutions. }\end{array}$} & Administrator & 273 & 3,96 & ,910 & 22,97 \\
\hline & Teacher & 916 & 3,35 & 1,03 & 30,74 \\
\hline & Parent & 395 & 3,11 & 1,09 & 35,04 \\
\hline \multirow[t]{3}{*}{ Motivates parents and school staff in a manner that increases work efficiency. } & Administrator & 273 & 3,90 & ,932 & 23,89 \\
\hline & Teacher & 916 & 3,28 & 1,10 & 33,53 \\
\hline & Parent & 395 & 3,07 & 1,02 & 33,22 \\
\hline \multirow{3}{*}{$\begin{array}{l}\text { Recognises parents and teachers for their contributions to the school - parent } \\
\text { collaboration. }\end{array}$} & Administrator & 273 & 4,12 & ,971 & 23,56 \\
\hline & Teacher & 916 & 3,38 & 1,15 & 34,02 \\
\hline & Parent & 395 & 3,30 & 1,17 & 35,45 \\
\hline \multirow[t]{3}{*}{ Average } & Administrator & 273 & 3,93 & ,727 & 18,49 \\
\hline & Teacher & 916 & 3,40 &, 865 & 25,44 \\
\hline & Parent & 395 & 3,23 &, 867 & 26,84 \\
\hline
\end{tabular}

According to Table 9, the arithmetic average of the opinions of administrators, teachers and parents on the level of the school administrators' level of ensuring the organisational climate in the process of organising parent participation efforts is, $\bar{X}_{\mathrm{A}}=3,93, \bar{X}_{\mathrm{T}}=3,40, \bar{X}_{\mathrm{P}}=3,23$. According to these results, it is seen that the skills required by the phase of 
developing human relations in the process of organising parent participation efforts is adopted at the level of frequently by school administrators, and at the level of sometimes by parents and teachers. These findings indicate that the organisational climate directly affecting administrators', teachers' and parents' emotions, opinions and behaviours is not at the required level at schools.

Table 10. Differences between Administrator, Teacher and Parent Opinions on the Organisational Climate Dimension in the Organisation of Parent Involvement Efforts

\begin{tabular}{|c|c|c|c|c|c|c|}
\hline Groups & $\mathrm{N}$ & $\bar{X}$ & SS & $\mathrm{Sd}$ & $\mathrm{t}$ & $\mathrm{p}$ \\
\hline Administrator & 273 & 3,93 & ,727 & 1187 & 9,331 &, $000^{*}$ \\
\hline Teacher & 916 & 3,40 &, 865 & & & \\
\hline Administrator & 273 & 3,93 & 727 & 666 & 11,043 &, $000^{*}$ \\
\hline Parent & 395 & 3,23 & ,867 & & & \\
\hline Teacher & 916 & 3,40 &, 865 & 1309 & 3,537 &, $001^{* *}$ \\
\hline Parent & 395 & 3,23 & ,867 & & & \\
\hline
\end{tabular}

$$
{ }^{*} \mathrm{p}<.001{ }^{* *} \mathrm{p}<.01
$$

According to Table 10, when the level of school administrators' skill in ensuring the organisational climate in the process of organising parent participation efforts is assessed in terms of the duty type variable, there appears a statistically significant difference $\left[\mathrm{t}_{(1-1188)=} 9,331, \mathrm{p}<.001\right]$ in favour of the administrator in the administrator-teacher group, $\left[\mathrm{t}_{(1-673)=} 11,043, \mathrm{p}<.001\right]$ in favour of the administrator in the administrator-parent group, and $\left[\mathrm{t}_{(1-1316)}=3,537\right.$, $\mathrm{p}<.01]$ in favour of the teacher in the teacher-parent group. Taking the averages into consideration, school administrators' skills in developing the organisational climate in the process of organising the parent participation efforts are considered adequate by administrators, while being considered inadequate by teachers and parents.

3.5 Differences between School Administrators' Skill Level in Organising Parent Involvement Efforts, According to Type of School

Table 11 presents average and standard deviation values regarding the level of school administrators' skill in organising parent participation efforts in terms of the school type variable according to the teachers' and parents' opinions.

Table 11. Averages and Standard Deviation Values Regarding School Administrators' Level of Skill in Organising Parent Involvement Efforts, According to School Type

\begin{tabular}{llllll}
\hline Organising Dimensions & School Type & $\mathrm{N}$ & $\bar{X}$ & $\mathrm{SS}$ & $\mathrm{V}$ \\
\hline Construction & Primary School & 435 & 3.54 & .858 & 24,23 \\
& Secondary School & 452 & 3.29 & .752 & 22,85 \\
& High School & 424 & 3.38 & .740 & 21,89 \\
& Total & 1311 & 3.40 & .791 & 23,26 \\
& Primary School & 435 & 3.00 & 1.01 & 33,66 \\
& Secondary School & 452 & 2.76 & .876 & 31,73 \\
& High School & 424 & 2.79 & .876 & 38,25 \\
\multirow{5}{*}{ Staffing and Equipping } & Total & 1311 & 2.85 & .928 & 32,56 \\
& Primary School & 435 & 3.33 & .995 & 29,87 \\
& Secondary School & 452 & 3.04 & .852 & 28,02 \\
& High School & 424 & 3.22 & .955 & 29,65 \\
Organisational Climate & Total & 1311 & 3.19 & .941 & 29,49 \\
& Primary School & 435 & 3.52 & .964 & 27,38 \\
& Secondary School & 452 & 3.21 & .809 & 25,20 \\
& High School & 424 & 3.31 & .797 & 24,07 \\
& Total & 1311 & 3.34 & .869 & 26,01 \\
\hline
\end{tabular}

According to Table 11, when teacher and parent opinions on school administrators' level of skill in organising parent participation efforts according to the school type variant is examined, it is observed that the arithmetic averages drop when proceeded from primary school to high school. 
Table 12 presents the ANOVA results in which whether the level of skill of school administrators in organising parent participation efforts differ according to the school type variable is assessed.

Table 12. ANOVA Results Regarding the Level of Skill of School Administrators in Organising Parent Involvement Efforts in Terms of the School Type Variable According to Teacher and Parent Opinions

\begin{tabular}{llllllll}
\hline & & KT & Sd & KO & F & p & Difference \\
\hline Construction & Inter-Groups & 13.622 & 2 & 6.811 & 11.038 & $.000^{*}$ & $1-2,1-3$ \\
& Intra-Group & 807.077 & 1308 & .617 & & & \\
Total & 820.698 & 1310 & & & \\
& Inter-Groups & 14.198 & 2 & 7.099 & 8.330 & $.000^{*}$ & $1-2,1-3$ \\
& Intra-Group & 1114.694 & 1308 & .852 & & & \\
Staffing and Equipping & Total & 1128.892 & 1310 & & & \\
& Inter-Groups & 18.258 & 2 & 9.129 & 10.439 & $.000^{*}$ & $1-2,3-2$ \\
& Intra-Group & 1143.936 & 1308 & .875 & & & \\
& Total & 1162.195 & 1310 & & & \\
& Inter-Groups & 22.470 & 2 & 11.235 & 15.179 & $.000^{*}$ & $1-2,1-3$ \\
& Intra-Group & 968.144 & 1308 & .740 & & & \\
\hline
\end{tabular}

$*_{\mathrm{p}}<.001$

Examining Table 12, it is observed, according to the ANOVA results, that there are differences in school administrators' skills in organising school parent participation efforts according to the school type variable. All school administrators attempt to organise parent participation efforts in similar manners in spite of a difference in the teachers' and parents' perception of school-parent collaboration according to school types. This, in turn, causes school administrators to be considered inadequate in organising parent participation efforts.

\section{Conclusion and Discussion}

In the study, administrators' process of organising parent participation efforts was taken in the 'construction, works required, staffing and equipping, and organisational climate' dimensions. From among their skills in organising parent participation efforts, the school administrators participating in the study considered their construction, staffing and equipping and organisational climate skills important, while insufficiently adopting their skills regarding organisational climate. According to teachers and parents participating in the study, school administrators' skills in organising parent participation efforts are not at the required level when considering the organisation steps. The conclusion that school administrators do not regard the organising steps in the process of organising parent participation efforts was reached.

According to the research findings, during the construction process, which constitutes the first step in the process of organising parent participation efforts, the realisation level of 'the steps of conducting research on school-parent collaboration, determining the objectives of school-parent collaboration in line with the needs of teachers, parents and students, and classification according to the types of school-parent works' is low. However, the construction phase has a direct impact on the organisation process in realising the required objectives of parent participation efforts to be carried out within the scope of school-parent collaboration. For this reason, the school administrator must have the skills to carry out the arrangements necessary to ensure the multi-faceted participation of parents in line with the school's needs during the construction process.

On this issue, Nural (2010) emphasises the fact that school-parent collaboration will be successful only when organised as multi-purpose, well-planned and long-term. These results may be interpreted as an incompliance with the construction phase, which is the first step of the organisation process in establishing school-parent associations. This indicates that school administrators must demonstrate the skills expected of them and meet the parents' expectations in the construction phase, which is the most important step of organising efforts addressing school-parent collaboration and which will set the course of the other phases.

School administrators' attitude towards parent participation efforts is an important factor in determining the scope of the applications. Administrators' recognition of the obstacles before parent participation efforts will ensure the provision of opportunities for parent participation. Therefore, especially administrators must believe that school-parent collaboration is very important in actualising the school's objectives. If parent participation effort are given the necessary value and are addressed seriously, parent participation types and strategies shall develop on their own accord (Lebahn, 1995; Qumette, Feldman and Tung, 2002; Peiffer, 2003; DeHass, 2005, Coyote, 2007).

The study reached the conclusion that, according to administrators, teachers and parents, arrangements allowing parent participation efforts are not adequately made. According to Funkhouser, Gonzales (1997), schools must provide the necessary facilities and conditions to enable parents to participate in their children's education, while administrators, teachers and other assisting staff must take a close interest in families. Environments where families are able to explain 
their wishes, expectations and problems and where they are able to participate in the decision-making process must be created. Families must be provided with education on the reasons and benefits of parent participation efforts. Berger (1987) emphasises that parents with knowledge of the structure, values and operating mode of the school provide their children with multi-faceted support.

The study found that planning for determining and classifying the parent participation efforts carried out to the end of school-parent collaboration is required. This indicates that school administrators must self-criticise with respect to determining the works to be carried out, which is the second step of organising school-parent collaboration, must develop themselves in this matter, and must demonstrate their skills on the process.

The study yielded the result that teachers and parents found administrator skills regarding staffing and equipping in organising parent participation efforts inadequate. This result may be interpreted to mean that teachers and parents consider the procedure followed in determining the parents and teachers to be charged with duties in parent-teacher associations and other teams established at schools ineffective. Also, in the light of the results obtained, it may be said that teachers and parents have insufficient knowledge on the responsibilities and powers their tasks place on their teams. Especially in the staffing and equipping phase, the type of the task, and the interests, wishes and abilities of the person to be charged with the task must be taken into consideration, and duties must be assigned based on democratic methods and on voluntary basis. For this, the school administrator must possess staffing and equipping skills in addition to a good knowledge of the personnel to be assigned. This indicates that the necessary manpower must be integrated into the process under the consensus of all stakeholders of the school community in carrying out school-parent collaboration efforts in the staffing and equipping phase, which is the third step of organising school-family collaboration.

The study revealed that the school administrations' attitude and behaviour towards school - family collaboration was not adequate. This affects the climate at the school as well as the parents' attitude and behaviour towards the school administration. Ensuring that teachers and other school stakeholders work together in a more collaborative atmosphere is related to reshaping the school culture and school administrators' giving importance to emotion management with respect to relations between individuals at school (Katzenmeyer and Moller, 2013, 91). School - family collaboration must be used in its multiple aspects in creating a climate that would have a positive effect on the attitude of parents and teachers at schools (Rosenblatt and Peled, 2002; Akan, 2017).

To this end a multi-faceted communications network must be established at schools. For the type of communication, the channels, type and duration of communication directly affects the school's climate. According to Burns, Roe and Ross (1992), regular communication established between parents and teachers is very important. Communicating with parents on activities at school, information sharing prepared on the rules and order of the school as well as on information needed by the parent are the traditional tools of this communication to be established. Personal reports on students, telephone conversations, parent - teacher meetings, face to face interviews for special discussions and dialogue regarding the child, house calls, and days on which parents are able to see class activities are methods of communication that have been practiced for many years. Within this context, it may be said that school administrators fail to make the best use of internal and external dynamics capable of bringing together all of the stakeholders of the school during the phase of ensuring the organisational climate, which is the last step of organising school - family collaboration.

According to the findings of the study, school administrators do not have adequate skills in creating opportunities to develop school - parent collaboration, motivating parents and school staff, and appreciating parents and teachers. However, schools must appreciate school staff, volunteer families, the community and partners for sparing time for, and contributing to, developing the effectiveness of parent participation programmes. Family members who visit the classroom, assist the teacher or read most can be appreciated (Blank, Heifets, Shah and Nissani, 2004; Epstein and Jansorn, 2004b; Wherry, 2002; Giba, 1999).

According to teacher and parent opinions in terms of the school type variable, scores regarding school administrators' skill in organising parent participation efforts drop as they proceed from primary school to high school. It was concluded that school-family collaboration is more intense at primary school, and that the participants' perception of school-parent collaboration varies according to school type.

This may arise from the fact that school - parent collaboration is more effective at primary school, and that school parent collaboration decreases during the process towards high school. The obtained findings may also be interpreted as meaning that the purposes of school - family collaboration and the expectations and demands of the administration teachers-parents-students vary according to school types. According to Epstein and Connors (1994), there are many reasons for the fact that the partnership between school-parent and community is more widespread at primary schools compared to secondary schools and high schools. The first among these reasons is the attitude of some teachers and parents who believe that high school students are more conscious and mature individuals, who would not need their 
parents' participation during the education process.

A study conducted by Caskey (2008) on seventh- and eighth-grade students expresses that, in spite of the widespread belief on adolescents who do not want their families' participation in activities regarding school and who have started to move away from their parents, the research results support the important role played by families in the school success and social development of adolescents. Also Wheeler (1992), Eccles and Harold (1993) indicate that joint action by the school and the family during high school accelerates the healthy development of the adolescent, and that family participation proves an important factor in increasing attendance, supporting the student's success, reducing discipline issues, and raising productive and all-around healthy young adults.

Nural (2010) emphasises that school - family collaboration is very effective and important not only for primary schools, but also for high schools. The school administrator has an important responsibility in this. School-family collaboration must be equally important in all educational institutions. This is related to the importance given by the school administrator and the teachers to school - family collaboration.

Although parent participation efforts are taken into consideration in all educational institutions, the increase in students' individual representation power is effective in the weakening of school - family collaboration towards high school. However, school - family collaboration, especially in high school years, is very important to ensure that individuals who will continue with their undergraduate or graduate studies or acquire a profession after high school meet the demands of social life. Therefore, parent participation efforts must be configured according to school type.

\section{Suggestions}

The parent-teacher association regulation in force is not adequate in increasing collaboration between the school and the family, and therefore more effective parent-teacher association models taking school types into consideration may be developed. School-parent collaboration must be reconfigured in accordance with school types, student demands and parent expectations in line with Law No. 3308 on Vocational Education. The collaboration between universities and the Ministry of National Education must be strengthened with respect to school-environment relations, administrators and teachers must be provided with knowledge and skills in school-family relations. The socio-economic and socio-cultural statuses of parents must not be seen as a factor that undermines school-parent collaboration, but as an opportunity to develop school-family collaboration, and consideration must be given on how to activate and develop parent competence. While organising parent participation efforts, school administrators must consider the school's and parents' demands, expectations, wishes and requests, and must conduct a preliminary feasibility study to this end.

\section{References}

Akan, D. (2017). Effective school evaluation in primary schools from the dimension of parents, Journal of Education and Training Studies, 5(1), 134-140. https://doi.org/10.11114/jets.v5i1.2094

Akbaşlı, S., \& Kavak, Y. (2008). Ortaöğretim Okullarındaki Okul Aile Birliklerinin Görevlerini Gerçekleştirme Düzeyleri, Selçuk Üniversitesi Sosyal Bilimler Enstitüsü Dergisi, 19, 1-22.

Aydoğan, İ. (2006). İlköğretim Okullarında Okul-Çevre İlişkilerinin Düzeyi, Sosyal Bilimler Araştırmaları Dergisi, 2, 121-136.

Aytaç, T. (2000). Eğitim Yönetiminde Yeni Paradigmalar Okul Merkezli Yönetim. Ankara: Nobel Yayın Dağıtım.

Bayrakçı, M., \& Dizbay, S. (2013). Ortaöğretim Kurumlarında Okul Aile Birliklerinin Okul Yönetimine Katılım Düzeyleri, Sakarya University Journal of Education, 3(1), 98-112.

Berger, E. H. (1987). Parent Involvement: Yesterday and Today. The Elementary School Journal, 3, 96-108.

Blank, M., Heifets, O., Shah, B., \& Nissani, H. (2004). Community Schools: Engaging Parents and Families. Principal, 83(3), 18-21.

Burns, C. P., Roe, B. D., \& Ross, E. P. (1992). Teaching Reading İn Today's Elementary Schools, Boston: Houghton Mifflin Company.

Caskey, M. M. (2008). Parents' Relationships and Involvement: Effects on Students' School Engagement and Performance, Online Research in Middle Level Education, 31(10), 1-11.

Coyote, C. (2007). Principal Attıtudes Toward Parental Involvement In South Dakota Secondary Schools, Ph. D. dissertation, University of South Dakota, USA.

Danielson, C. (2002). Enhancing student achievement: A framework for school improvement. Association for Supervision \& Curriculum Development, Alexandria, VA, USA.

DeHass, A. G. (2005). Facilitating Parent Involvement: Reflecting on Effective Teacher Education, Teaching and 
Learning, 19(2), 56-57.

Dempsey, K., Battiato A. C., Walker, J. M. T., \& Reed, R. P. (2001). Educational Psychologist, Parental Involvement in Homework, 36(3), 195-209.

Eccles, J. S., \& Harold, R. D. (1993). Parent-School Involvement during the Early Adolescent Years, Teachers College Record, 94, 568-587.

Epstein, J. L. (1995). School/family/community partnerships: Caring for the children we share. Phi Delta Kappan, 76(9), 701-712.

Epstein, J. L., \& Connors, L. J. (1994). School, Family And Community Partnerships In High Schools, (Report 24). Baltimore, Md: Johns Hopkins University, Center on Families, Communities, Schools and Children's Learning.

Epstein, J. L., \& Jansorn, N. R. (2004b). Developing Successful Partnership Programs. Principal, 83(3), 10-15.

Epstein, J. L., \& Jonsorn, N. R. (2004a). School, Family and Community Partnerships Link the Plan. The Educatıon Digest, 69(6), 19-23.

Fantuzzo, J., McWayne, C., Perry, A. M., \& Childs, S. (2004). Multiple dimensions of family participation and learning competencies for urban, low-income children. School Psychology Review, 33(4), 467-480.

Funkhouser, J. E., \& Gonzales, M. R. (1997). Family Involvement in Children's Education - An Idea Book. Washington, D.C.: Government Printing Office.

Gestwicki, C. (2004). Home, school, and community relations (5th ed.). USA: Delmar Learning.

Giba, M. A. (1999). Forging Partnerships between Parents and Teachers. Principal, 78(3), 33-35.

Katzenmeyer, M., \& Moller, G. (2013). Uyuyan Devi Uyandırmak Öğretmen Liderler Yetiştirmek (tr. Ed.Servet Özdemir). Ankara: Nobel Akademik Yayıncılık.

Lebahn, J. (1995). Education and Parental Involvement in Secondary Schools: Problems, Solutions, and Effects, Educational Psychology Interactive. Valdosta, GA: Valdosta State University. Retrieved 15 June 2016 from http://www.edpsycinteractive/files/parinvol.html

Lındberg, E. N. (2014). Eğitim Fakültesi Son Sınıf Öğrencilerinin Aile Katılımı ile İlgili Görüşleri, Kuram ve Uygulamada Ĕgitim Bilimleri Dergisi, 14(4), 1339-1361.

MEB (2005). Okul-Aile Birliği Yönetmeliği. Resmi Gazete, 25831(31), 6-7.

MEB. (1997). İlköğretim Okulları El Kitabı. Ankara: İlköğretim Genel Müdürlüğü.

Nural, E. (2010). Okul Çevre İlişkileri ve Okula Toplumsal Katılım. Salih Akyıldız (Ed.). Türk Eğitim Sistemi ve Okul Yönetimi içinde (s. 209-238). Trabzon: Celepler Matbaacılık.

Nural, E., Kaya, C. D., \& Kaya, Y. (2013), Okul Aile Birliklerinin İşleyişi, Sorunlarına İlişkin Yöneticilerin, Okul Aile Birliği Üyelerinin Görüşleri, Eğitim ve Öğretim Araştırmaları Dergisi, 2(4), 58-69.

Özbaş, M., \& Badavan, Y. (2009). İlköğretim Okulu Yöneticilerinin Okul-Aile İlişkileri Konusunda Yapmaları Gereken ve Yapmakta Oldukları İşler. Eğitim ve Bilim Dergisi, 34(154), 69-81.

Parker, L. F., Boak, Y. A., Griffin, W. K., Ripple, C., \& Peay, L. (1999). Parent-child relationship, home learning environment, and school readiness. School Psychology Review, 28(3), 413-425.

Peiffer, P. (2003). An examination of attitudes of high school principals toward parental participation in Michigan's schools (Doctoral dissertation, Central Michigan University). Dissertations International Abstracts, 64(02), 63.

Quimette, M.Y., Feldman, J., \& Tung, R. (2002). Collaborating for High School Student Success: A Case Study of Parent Engagement at Boston Arts Academy, The School Community Journal, 16(2), 91-114.

Riley, R. W. (1994). Strong Families, Strong Schools: Building Community Partnerships for Learning, A Research Base for Family Involvement in Learning from the U.S. Department of Education.

Rosenblatt, Z., \& Peled, D. (2002), School Ethical Climate and Parental Involcement. Journal of Educational Administration, 40(4), 349-367. https://doi.org/10.1108/09578230210433427

Şişman, M. (2002). Eğitimde Mükemmellik Arayışı Etkili Okullar, Ankara: Pegem A Yayıncılık.

Şişman, M., \& Turan, S. (2002). Eğitim ve Okul Yönetiminde Eğitim Bölgesi Danışma Kurullarının İşlevi, Eğitim Araştırmaları Dergisi, 2, 136-146.

Tavşancıl, E. (2006). Tutumların Ölçülmesi ve SPSS ile Veri Analizi, Ankara: Nobel Yayın Dağıtım. 
Türkmen, Ş. (2005). Okullarda Yönetim Etkinlikleri, Ankara: Alp Yayınları.

Wheeler, P. (1992). Promoting Parent Involvement in Secondary Schools. NASSP Bulletin, 76(546), 28-35. https://doi.org/10.1177/019263659207654606

Wherry, J. H. (2002). Planning Ahead for Parent Involvement, Principal, 81(5), 53-54.

Yiğit, B., \& Bayrakdar, M. (2006). Okul Çevre İlişkileri, Ankara: Pegem A Yayıncılık.

Yılmaz, H. (1994). 21. Yüzyılın Eşiğinde Ülkemizde Okul Aile İşbirliği, M. ̈. Atatürk Eğitim Fakültesi Eğitim Bilimleri Dergisi, 6, 301-312.

\section{Copyrights}

Copyright for this article is retained by the author(s), with first publication rights granted to the journal.

This is an open-access article distributed under the terms and conditions of the Creative Commons Attribution license which permits unrestricted use, distribution, and reproduction in any medium, provided the original work is properly cited. 